\title{
Fragmentation of Bacteriophage S13 Replicative Form DNA by Restriction Endonucleases from Hemophilus influenzae and Hemophilus aegyptius
}

\author{
FRANK G. GROSVELD, KAIE M. OJAMAA, AND JOHN H. SPENCER \\ Department of Biochemistry, McGill University, 3655 Drummond Street, \\ Montreal, Quebec, Canada H3G 1 Y6 \\ Accepted October 14, 1975
}

\begin{abstract}
The restriction enzymes $H$ ind from Hemophilus influenzae and Ilae ${ }_{\text {III }}$ from Ilemophilus aegyptius cleave bacteriophage $\mathrm{S} 13$ replicative form (RF) DNA into 13 and 10 specific fragments, respectively. The sizes of these fragments were estimated by gel electrophoresis, electron micruscopy, and pyrimidine isostich analysis. The $H$ ind and $H e_{\text {III }}$ fragments were ordered relative to each other by cross digestion and a physical map of the S13 genome constructed. Comparison of the Hind cleavage patterns of S13 RF DNA and $\phi \mathrm{X} 174 \mathrm{RF}$ DNA showed the majority of the fragments from the two DNAs coincided with each other except for three of the thirteen $\mathrm{S} 13$ fragments and three of the thirteen $\phi \times 174$ fragments. Comparison of the $\mathrm{Hae}_{\mathrm{III}}$ patterns of the two DNAs revealed a lack of coincidence of one S13 fragment only and two $\phi$ X174 fragments. From the data obtained by the cleavage of the two DNAs by Hind and $\mathrm{Hae}_{111}$, a correlation between the physical restriction enzyme cleavage maps and the genetic map of the two phages was made. The differences in cleavage of the two DNAs by the restriction enzymes have been explained by changes in two restriction enzyme sites in the $A B$ region and one change of site in the $F$ region of the genetic map of the two bacteriophages.
\end{abstract}

\section{INTRODUC'TION}

The DNAs of the small icosahedral bacteriophages $\phi \mathrm{X} 174$ and S13 are attractive for sequence determination because the genomes consist of only approximately 5000 nucleotides (Sinsheimer, 1968; Spencer et al., 1972; Berkowitz and Day, 1974). Previous studies in our laboratory described the total pyrimidine-purine oligonucleotide catalog of bacteriophage $\mathrm{S} 13$ and S13 replicative form (RF) DNA (Cerny et al., 1969) and the long pyrimidine oligonucleotides have been sequenced recently (Delaney and Spencer, 1973; Harbers et al., 1976). As an extension of these studies, and to obtain larger oligonucleotides containing all four bases, we have utilized the restriction enzymes from Hemophilus influenzae (Smith and Wilcox, 1970) and $\mathrm{He}$ mophilus aegyptius (Middleton et al., 1972) to obtain specific fragments of bacteriophage S13 RF DNA. Comparison of the physical maps of the restriction fragments and the sizes of the S13 RF fragments with the fragments obtained from $\phi \times 174$ DNA (Edgell et al., 1972; Middleton et al., 1972; Lee and Sinsheimer, 1974) using the two enzymes revealed three changes in location of the restriction endonuclease sites between the two DNAs.

Nomenclature. The nomenclature system proposed by Smith and Nathans (1973) for describing the restriction-modification enzymes has been followed. The enzyme preparation from $H$. influenzae strain Rd is designated Hind and comprises both Hind $\mathrm{d}_{\mathrm{II}}$ and Hind $\mathrm{d}_{\mathrm{III}}$ enzymes since separation of these different activities was not attempted. The enzyme preparation from H. aegyptius is designated $\mathrm{Hae}_{\mathrm{III}}$. The nomenclature system of the DNA fragments departs from that proposed by Smith and Nathans (1973). The fragments have been assigned arabic numerals in or- 
der of decreasing size as determined by electrophoretic separation on polyacrylamide gels. Thus S13 Hind 2 is the second largest fragment released by endonuclease Hind from bacteriophage S13 RF DNA. In the case of two or more fragments of the same apparent size the designations are followed by the letters $a, b$, c, etc. The nomenclature has been chosen deliberately to avoid confusion between fragments of similar size released from different DNA substrates by various restriction enzymes and between the letters of the genetic map. Fragments obtained by complete digestion with both endonucleases Hind and $H_{a e_{\text {III }}}$ either concomitantly or serially are designated $\mathrm{HH}$, followed by a number indicating the number of base pairs in the fragment. Thus, $\mathrm{S} 13 \mathrm{HH} 470$ is a fragment of 470 base pairs released from S13 RF I DNA by complete digestion with endonucleases Hind plus $H_{a e_{I I I}}$. Fragments obtained by partial digestion with either or both endonucleases are designated $\delta$ followed by a number indicating the number of base pairs in the fragment. The enzyme (or enzymes) and starting material used are defined separately for each $\delta$ fragment.

\section{MATERIALS AND METHODS}

Materials. Bacteriophage S13 wild-type was kindly supplied by Drs. I and E. Tessman. Chloramphenicol, ethidium bromide, and bovine serum albumin (Fraction V) were obtained from Sigma Chemical Co. and streptomycin sulphate was obtained from Calbiochem. Optical grade $\mathrm{CsCl}$ was from the Harshaw Chemical Co. DEAE Sephadex A-25 was obtained from Pharmacia (Canada) Ltd., and $\mathrm{H}_{3}{ }^{32} \mathrm{PO}_{4}$ was obtained from New England Nuclear (Canada) Ltd. Reagents for electrophoresis, acrylamide and bis $\left(N, N^{\prime}\right.$-methylenebis (acrylamide)), were obtained from Eastman. The acrylamide was recrystallized from chloroform before use.

Isolation of ${ }^{32} P$-labeled replicative form 1 DNA from bacteriophage $S 13$ wild type. Growth was performed as described by Shleser et al. (1968). After collection of the cells by centrifugation the superhelical replicative form DNA (RF I) was isolated from the total DNA as described by Schekman et al. (1971) except for one modification. The pooled fractions from the ethidium bromide- $\mathrm{CsCl}$ gradient centrifugation were extracted with isopropanol three times to remove the ethidium bromide directly, and then concentrated by vacuum dialysis against $10 \mathrm{mM}$ Tris-HCl buffer, $\mathrm{pH}$ 7.6. This eliminated the necessity for isopropanol precipitation and redissolving of the DNA with the concomitant losses.

Purification of restriction endonuclease Hind. Endonuclease Hind was isolated from $H$. influenzae strain $\mathrm{Rd}$ (obtained from Dr. D. Denhardt from Dr. N. Axelrod), according to the method of Smith and Wilcox (1970) but modified by replacement of the agarose column step by streptomycin sulphate precipitation as follows: To the clarified sonicate of the cell suspension, $1 \mathrm{ml}$ of $10 \%$ streptomycin sulphate, in $50 \mathrm{~m} M$ Tris- $\mathrm{HCl}$ buffer, $\mathrm{pH} 7.4$, containing $2 \mathrm{~m} M$ dithiothreitol, was added for each $1500 A_{260}$ units of solution. The solution was stirred for $15 \mathrm{~min}$ on ice and the precipitate was removed by centrifugation. Precipitation of the nucleic acids was monitored by measurement of the ratio $A_{230} \mathrm{o}$ $A_{26} 0$ and additional streptomycin sulphate added until the ratio attained 2 to 2.5 . The supernatant solution was then diluted according to the original procedure prior to ammonium sulfate precipitation. Enzyme activity from the phosphocellulose column chromatography step was detected by alcohol precipitation of calf thymus DNA. To $20 \mu \mathrm{l}$ of each column fraction were added $20 \mu \mathrm{l}$ of a $2 \mathrm{mg} / \mathrm{ml}$ calf thymus DNA solu-

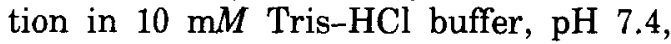
containing $6 \mathrm{mM} \mathrm{MgCl}_{2}$ and the mixture was incubated at $37^{\circ}$ for $30 \mathrm{~min}$. The samples were placed in an ice bath and $50 \mu \mathrm{l}$ of $0.3 \%$ bovine serum albumin followed by $200 \mu$ l of cold $95 \%$ ethanol was added. Enzyme activity was revealed by a uniform milky solution; a clumped white precipitate indicated that no enzyme was present (D. 'T. Denhardt, personal communication). The enzyme activity eluted from the phosphocellulose column in a broad peak between 0.315-0.34 $M \mathrm{KCl}$. Fractions containing the enzyme were pooled, dialyzed against $20 \mathrm{mM}$ Tris- $\mathrm{HCl}$ buffer, $\mathrm{pH}$ 7.4, 
containing $0.2 \mathrm{M} \mathrm{NaCl}$ in $50 \%$ glycerol, and stored at $-20^{\circ}$.

Purification of the restriction endonuclease $\mathrm{Hae}_{\mathrm{II}}$. Endonuclease $\mathrm{Hae}_{\mathrm{III}}$ was isolated from $H$. aegyptius (ATCC strain 11116) according to the method of Smith and Wilcox (1970), modified as described for the endonuclease Hind purification. The enzyme activity eluted from the phosphocellulose column between 0.35 and 0.4 $M \mathrm{KCl}$.

Digestion of DNA with restriction endonucleases Hind and Hae ${ }_{111}$. The conditions, amounts of enzyme, and ${ }^{32} \mathrm{P}$-labeled RF I DNA were used exactly as described by Edgell et al. (1972) and Middleton et al. (1972).

Gel electrophoresis. Separation of endonuclease $H$ ind and $H_{a e_{I I I}}$ fragments by acrylamide gel electrophoresis was as described by Edgell et al. (1972). The gels were prepared in glass tubes $6 \mathrm{~mm}$ in diameter $\times 15$ to $25 \mathrm{~cm}$ long. Electrophoresis was for 8 to $10 \mathrm{hr}$ at $4 \mathrm{~mA}$ per tube. Gels were sliced into 2-mm fractions using a Gilson aliquogel fractionator and collected in aqueous suspension directly into scintillation vials. In ${ }^{32} \mathrm{P} / 3 \mathrm{H}$ double-labeled experiments, the gel fractions were solubilized by incubation in $30 \% \mathrm{H}_{2} \mathrm{O}_{2}$ at $60^{\circ}$ overnight, $20 \mathrm{ml}$ Triton X-100 (Sebring et al., 1971) scintillation fluid was added, and the radioactivity was measured in a Beckman IS 250 liquid scintillation spectrometer. Counts were corrected for spill by a dual label correction program using a Beckman tape editor and Olivetti programma 101 fitted to accept punch tape. In experiments in which ${ }^{32} \mathrm{P}$ was the only radioisotope present, radioactivity was measured by Cerenkov radiation in a Beckman LS 250 liquid scintillation spectrometer. For further analysis the peak fractions were pooled and the DNA fragments were extracted from the gel by stirring for $5 \mathrm{hr}$ in $0.56 \mathrm{M} \mathrm{NaCl}$ solution. The extracted gel was removed by filtration through a fine-grade sintered glass filter and washed with $\mathrm{H}_{2} \mathrm{O}$. This procedure gave a better than $95 \%$ yield of ${ }^{32} \mathrm{P}$-labeled DNA fragments. Extracts of the smaller fragments were concentrated in a Buchler evapo-mix and extracts of the larger frag- ments were concentrated by lyophilization to avoid further shear degradation.

Slab gel electrophoresis was performed in a water-cooled vertical apparatus. Gels were $4-8 \%$ polyacrylamide, $0.3 \times 20 \times 20$ $\mathrm{cm}$ in size with a $4-\mathrm{mm} 0.6 \%$ agarose gel overlay for formation of the pockets $(5 \times 3$ $\mathrm{mm}$ ). Gels were run for 8 to $10 \mathrm{hr}$ at $75 \mathrm{~mA}$ per gel and the separated fragments were located by radioautography.

Pyrimidine isostich analysis. Pyrimidine oligonucleotides were released from DNA restriction enzyme fragments by formic acid/diphenylamine digestion as described by Burton (1967), and the diphenylamine was removed by ether extraction. Chain-length fractionation of the hydrolysate was performed on DEAE Sephadex A25 at $\mathrm{pH} 5.5$ as described elsewhere (Delaney and Spencer, in preparation). For identification of the long pyrimidine oligonucleotides in each fragment, the hydrolysates were evaporated to dryness, redissolved in water, and subjected to ionophoresis/homochromatography as described by Brownlee and Sanger (1969) and modified by Ling (1972).

Electron microscopy. Bacteriophage $\mathrm{S} 13$ RF DNA was used as a standard reference in electron microscopy of DNA Hind fragments prepared by the Kleinschmidt and Zahn technique (1959). Photomicrographs of the DNA molecules were projected and traced and the lengths were measured with a map measurer.

\section{RESULTS}

Size of fragments released by Hind and $\mathrm{Hae}_{\text {II }}$ from S13 RF I DNA. Digestion of ${ }^{32}$ P-labeled S13 RF I DNA by either endonuclease $\mathrm{Hind}$ or $\mathrm{Hae}_{\text {III }}$ followed by electrophoresis of the respective hydrolysate on a $3 \%$ polyacrylamide gel resulted in separation of both the Hind fragments and Hae fragments each into nine size classes. The results are shown in Fig. 1. The molecular weights of the various Hind and $\mathrm{Hae}_{\text {III }}$ fragments were calculated by integration of the counts per minute in each size class (peak) and expression of these values as a function of the 5000 base pairs per molecule of S13 RF I DNA (Spencer et al., 1972; Cerny et al., 1969). The results are given in 


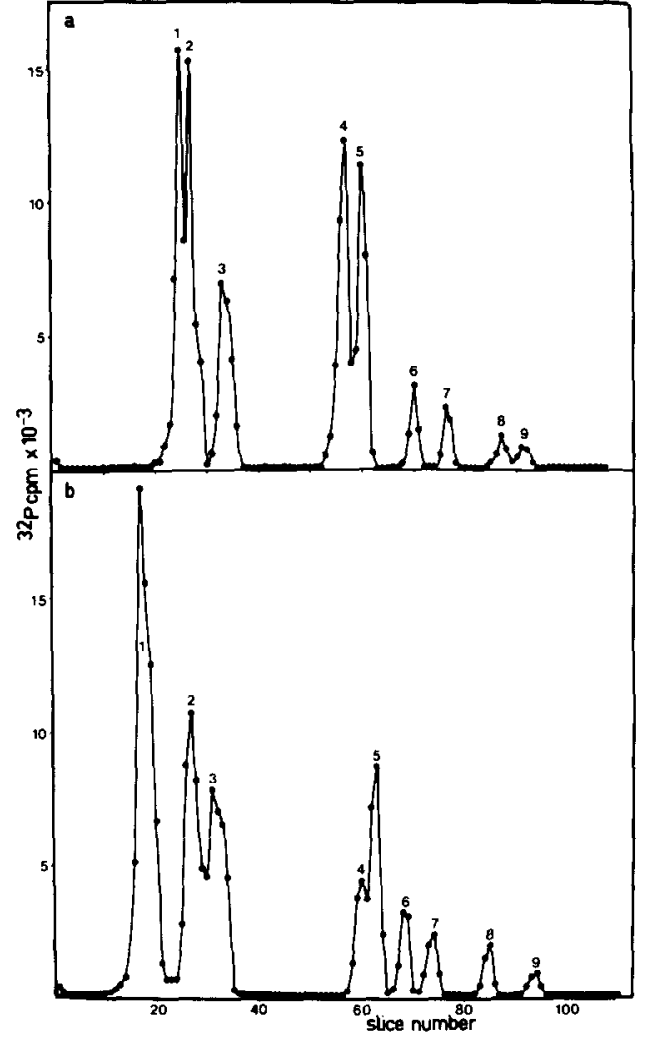

FIG. 1. Polyacrylamide gel electrophoresis of $\mathrm{S} 13$ RF I DNA fragments produced by (a) endonuclease $H$ ind and (b) endonuclease $H a e_{\mathrm{HI}}$. Twenty micrograms of ${ }^{32} \mathrm{P}$-labeled S13 RF I DNA, $6 \mathrm{mM}$ Tris-HCl (pH 7.6), $6 \mathrm{mM} \mathrm{MgCl}_{2}, 6 \mathrm{~m} M$ mercaptoethanol, 6 $\mathrm{mM} \mathrm{NaCl}$, and $50 \mu \mathrm{l}$ of endonuclease Hind (a) or $H a e_{\text {III }}$ (b) in a final volume of $300 \mu l$ were incubated at $37^{\circ}$ for $16 \mathrm{hr}$. The solution was evaporated under vacuum to approximately $40 \mu \mathrm{l} ; 1 \mu \mathrm{l}$ of bromophenol blue dye added as a marker and layered on a $6 \mathrm{~mm} \times$ $25 \mathrm{~cm} 3 \%$ polyacrylamide gel. Electrophoresis was at $4 \mathrm{~mA}$ per tube for $10 \mathrm{hr}$. Slices were $2 \mathrm{~mm}$ thick, giving a direct measure of the distance of migration (mobility in $\mathrm{mm}$ ) at the end of the run.

Tables 1 and 2, respectively. Edgell et al. (1972) have shown that a plot of the logarithm of the integrated counts in each peak (the relative masses) versus the electrophoretic mobility of $\phi \mathrm{X} 174 \mathrm{Hind}$ fragments in acrylamide gels provides an estimate of the number of fragments per molecule of $\phi \mathrm{X} 174 \mathrm{RF}$ I DNA in each electrophoretic peak and a confirmation of the size calculation of the fragments. A similar plot of the S13 Hind and Hae III fragments is presented in Fig. 2 which shows that all fragments, except Hind 4 and 5 from Fig. 1a and $\mathrm{Hae}_{\mathrm{III}} 5$ from Fig. $1 \mathrm{~b}$ fit a linear relationship corresponding to one Hind or $\mathrm{Hae}_{\mathrm{HI}}$ fragment per molecule of S13 RF I DNA. Size classes (peaks) Hind 4

TABLE 1

Size Determinations of the Fragments Released by Endonuclease Hind from BaCteriophage S13 RF I DNA

\begin{tabular}{|c|c|c|c|c|}
\hline $\begin{array}{l}\text { Hind } \\
\text { frag- } \\
\text { ments }\end{array}$ & $\begin{array}{l}\text { Num- } \\
\text { ber of } \\
\text { frag- } \\
\text { ments }\end{array}$ & $\begin{array}{l}\text { Size from inte- } \\
\text { gration of dpm } \\
\text { in base pairs } \\
\pm \mathrm{SEM}^{\alpha}\end{array}$ & $\begin{array}{c}\text { Size } \\
\text { from } \\
\text { elec- } \\
\text { tron } \\
\text { mi- } \\
\text { cros- } \\
\text { copy } \\
\text { in } \\
\text { base } \\
\text { pairs }\end{array}$ & $\begin{array}{l}\text { Size from } \\
\text { pyrimi- } \\
\text { dine isos- } \\
\text { tich anal- } \\
\text { ysis in } \\
\text { base } \\
\text { pairs }\end{array}$ \\
\hline 1 & 1 & $1065 \pm 13(7)$ & 1080 & \\
\hline 2 & 1 & $963 \pm 12(7)$ & 920 & \\
\hline 3 & 1 & $721 \pm 13(7)$ & & \\
\hline 4 & 3 & $314 \pm 8(7)$ & & \\
\hline 5 & 3 & $279 \pm 6(7)$ & & \\
\hline 6 & 1 & $192 \pm 5(7)$ & & \\
\hline 7 & 1 & $143 \pm 5(7)$ & & 156,154 \\
\hline 8 & 1 & $78 \pm 2(4)$ & & \\
\hline 9 & 1 & $59 \pm 2(4)$ & & \\
\hline
\end{tabular}

"The numbers in parentheses refer to the number of determinations used to calculate the standard error of the mean (SEM). The number of base pairs in S13 RF DNA has been calculated as $\mathbf{5 0 0 0 .}$

TABLE 2

Size Determination of the Fragments Released by EndonUClease $\mathrm{Ha}_{\text {III }}$ From BACTERIOPHAGE S13 RF I DNA

\begin{tabular}{cccc}
$\begin{array}{c}\mathrm{Hae}_{\mathrm{m}} \\
\text { frag- } \\
\text { ments }\end{array}$ & $\begin{array}{c}\text { Number } \\
\text { of frag- } \\
\text { ments }\end{array}$ & $\begin{array}{c}\text { Size from inte- } \\
\text { gration of dpm } \\
\text { in base pairs } \\
\pm \text { SEM" }\end{array}$ & $\begin{array}{c}\text { Size from } \\
\text { pyrimidine } \\
\text { isostich } \\
\text { analysis in } \\
\text { base pairs }\end{array}$ \\
\hline 1 & 1 & $1690 \pm 77(5)$ & \\
2 & 1 & $1025 \pm 13(5)$ & \\
3 & 1 & $863 \pm 24(5)$ & \\
4 & 1 & $298 \pm 10(5)$ & \\
5 & 2 & $270 \pm 8(5)$ & \\
6 & 1 & $218 \pm 7(5)$ & \\
7 & 1 & $170 \pm 7(5)$ & \\
8 & 1 & $107 \pm 4(5)$ & 108 \\
9 & 1 & $73 \pm 2(5)$ &
\end{tabular}

" The numbers in parentheses refer to the number of determinations used to calculate the standard error of the mean (SEM). The number of base pairs in S13 RF DNA has been calculated as 5000 . 


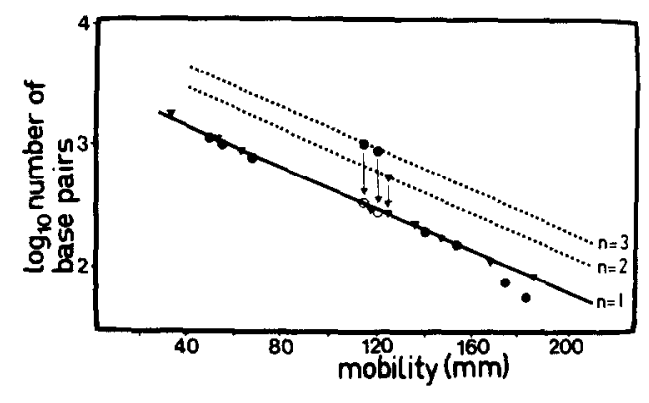

Fig. 2. Relationship between the logarithm of the number of base pairs and electrophoretic mobility of the Hind and $H_{a e_{\text {III }}}$ fragments of S13 RF I DNA. The number of base pairs was calculated from the integral of the counts in each peak of Fig. 1 and Fig. 3 as a function of the 5000 base pairs per molecule of S13 RF I DNA. The mobility was the distance migrated during the experiments (see legend to Figs. 1 and 3). The parallel lines (.....) were calculated for peaks with two or three times the mass ( $n$ $=2, n=3$ ) per molecule of S13 RF I DNA. The solid circles are the Hind fragments and the solid triangles are the $\mathrm{Hae}_{\text {III }}$ fragments. The open circles and open triangles are S13 Hind 4 and 5 and $\mathrm{S} 13 \mathrm{Hae}_{\mathrm{III}} 5$, respectively, after adjustment $(1 / 3$ or $1 / 2$, respectively) of their values to $n=1$.

and 5 fit a parallel line calculated for fragments three times the unit mass $(n=3)$ and thus contained $3 \mathrm{Hind}$ fragments each per molecule of S13 RF I DNA. Size class (peak) $\mathrm{Hae}_{\mathrm{III}} 5$ fits a parallel line calculated for $n=2$ and thus contained $2 \mathrm{Hae}_{\mathrm{III}}$ fragments per molecule of S13 RF I DNA.

A second procedure used for determination of the molecular weight of the largest S13 Hind fragments was measurement of the length of the two fragments, Hind 1 and $H i n d 2$ from electron micrographs of mixed samples of peaks 1 and 2 from Fig. 1a. A histogram of the measurement is shown in Fig. 3. The values 1080 and 920 base pairs (Fig. 3) compare favorably with the sizes calculated from the integral of the total radioactivity (Table 1).

A third method used to determine the size of the S13 fragments was pyrimidine isostich analysis (Cerny et al., 1969). S13 Hind 7 and $H_{a e_{I I I}} 8$ were hydrolyzed with formic acid/diphenylamine and each hydrolysate chromatographed individually on DEAE Sephadex A-25 to separate the pyrimidine oligonucleotides released according to chain length. The distribution of the pyrimidine isostichs is given in Ta- ble 3 and calculation of the number of tracts (Cerny et al., 1969) gave the total number of nucleotides in S13 Hind 7 and $H_{a e_{\text {III }}} 8$ as 156 and 108, respectively. The results correlate well with the sizes calculated from the integral of the total radioactivity (Tables 1 and 2).

Determination of the relative position of the Hind and Hae ${ }_{I I I}$ fragments of S13 RF I $D N A$ in a fragment map. The Hind and $H_{a e_{\text {III }}}$ fragments from S13 RF I DNA were ordered into a physical map by comparison

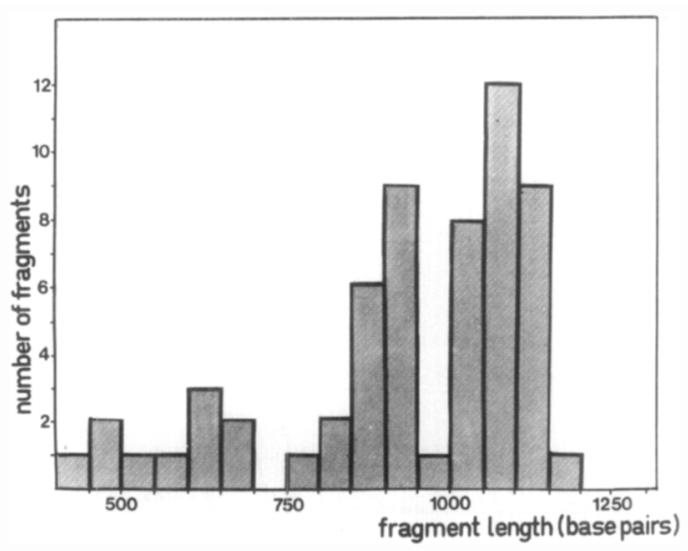

Fig. 3. Histogram of the length measurements of S13 Hind 1 and 2 from electron micrographs. The average lengths of the two major size classes were calculated as the mean values of 800 to 950 base pairs (920) and 1000 to 1150 base pairs (1080).

TABLE 3

Distribution of Pyrimidine Isostichs IN S13 Hind 7 AND S13 $\mathrm{Hae}_{\mathrm{III}} 8$

\begin{tabular}{|c|c|c|c|c|c|c|}
\hline \multirow[t]{2}{*}{$\begin{array}{l}\text { Py- } \\
\text { rimi- } \\
\text { dine } \\
\text { isos- } \\
\text { tichs }\end{array}$} & \multicolumn{2}{|c|}{$\begin{array}{l}\text { Moles py- } \\
\text { rimidine per } \\
100 \text { g atoms } \\
\text { DNA phos- } \\
\text { phorus }\end{array}$} & \multicolumn{2}{|c|}{$\underset{\text { Tracts }}{\text { Number of }}$} & \multicolumn{2}{|c|}{$\begin{array}{l}\text { Number of } \\
\text { Nucleotides }\end{array}$} \\
\hline & $\underset{7}{H i n d}$ & $\begin{array}{l}H_{8} e_{\text {III }} \\
\end{array}$ & $\underset{7}{H i n d}$ & $\begin{array}{l}H a e_{\mathrm{III}} \\
8\end{array}$ & $\underset{7}{\operatorname{Hind}}$ & $\begin{array}{c}H_{8} e_{\mathrm{III}} \\
\end{array}$ \\
\hline 1 & 0.28 & 0.29 & 31 & 32 & 31 & 32 \\
\hline 2 & 0.33 & 0.32 & 18 & 13 & 36 & 26 \\
\hline 3 & 0.27 & 0.14 & 10 & 5 & 30 & 15 \\
\hline 4 & 0.19 & 0.15 & 5 & 4 & 20 & 16 \\
\hline 5 & 0.09 & 0.07 & 2 & 2 & 10 & 10 \\
\hline 6 & 0.11 & $\mathrm{NP}^{n}$ & 2 & - & 12 & - \\
\hline 7 & 0.05 & NP & 1 & - & 7 & - \\
\hline 8 & NP & NP & - & - & - & - \\
\hline 9 & $\mathbf{N P}$ & 0.08 & - & 1 & - & 9 \\
\hline 10 & 0.08 & NP & 1 & - & 10 & - \\
\hline Total & 1.31 & 1.05 & & & 156 & 108 \\
\hline
\end{tabular}

"NP, not present. 
of the products produced from the fragments by various specific cross-digests with the opposite enzyme. All the fragments and products were separated by polyacrylamide slab gel electrophoresis and the results of the various cross digests are shown in Fig. 4. The size of each product was calculated from the mobility versus size plots as described in Fig. 2 and the results of the size calculations are summarized in Tables 4 and 5.

Comparison of separate $\mathrm{Hind}$ and $\mathrm{Hae}_{\mathrm{III}}$ digests with a combined Hind $+\mathrm{Hae}_{\mathrm{III}}$ total digest of S13 RF I DNA (Fig. 4a) indicated which fragments were to be further examined by cross-digestion to provide overlaps for the ordering of the fragments. The S13 Hind fragments 2, 4a, 5ab, 7, 8, and 9 were not cleaved by endonuclease $\mathrm{Hae}_{\text {III }}$ (Fig. 4a, Table 4) indicating that these fragments occur within a $\mathrm{Hae}_{\mathrm{III}}$ frag-

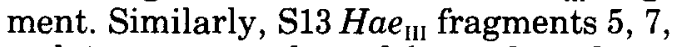
and 9 were not cleaved by endonuclease Hind and therefore occur within a Hind fragment (Fig, 4a, Table 5). To confirm these results each $H$ ind and $H_{a e_{I I}}$ fragment was isolated then digested separately with the opposite enzyme. The results showed that S13 Hind fragments 1, 3, $4 \mathrm{bc}, 5 \mathrm{c}$, and 6 and $\mathrm{Hae}_{1 \mathrm{II}}$ fragments 1, 2, 3, 4,6 , and 8 would provide the ordering information on cross digestion (Fig. 4).

The longer S13 $\mathrm{Hae}_{\text {III }}$ fragments 1 and 3 had more than three total cross digest products with $H$ ind (Fig. 4c). To determine the order of these products partial crossdigests of S13 Hae 1 II 1 and 3 with Hind in addition to complete digests were investigated.

Partial digestion of $\mathrm{S} 13 \mathrm{Hae}_{\mathrm{III}} 1$ by endonuclease Hind (Fig. 4b, Table 5) gave eight products; $H$ ind 2, 7, 9, two products HH510 and HH110 which were also present in a total Hind $+H_{a e_{\mathrm{II}}}$ digest of S13 RF I DNA and three products $\delta 1230, \delta 510$, and $\delta 750$ which did not correspond to any total Hind $+H_{a e_{I I I}}$ products and therefore must be partial hydrolysis products of S13 Hae $\mathrm{III}_{1} 1$. In order to show the presence of Hind 9 and $\mathrm{HH} 110$ in Fig. 4b the radioautograph was overexposed so that $\delta 1230, H a e 1$ and $H$ ind 2 blurred into each other. When the radioautograph was underexposed the three fragments were clearly delineated as separate bands (not shown). By examination of the size of all eight products from S13 $\mathrm{Hae}_{\text {III }}$ I (Table 5) one arrangement only is possible. $\delta 1230$ is a combination of $\mathrm{HH} 110+H$ ind $2+H$ ind $7, \delta 570$ a combination of $\mathrm{HH} 510+$ Hind 9 ; and $\delta 750$ a combination of HH510 + Hind $9+$ Hind 7 . Thus the sequence of fragments in $\mathrm{S} 13$ $H a e_{\text {III }} 1$ is:

$$
\frac{\text { HH110 }- \text { Hind 2-Hind 7 }}{\delta 1230}-\frac{\text { Hind 9 - HH510 }}{\delta 570}
$$

Partial digestion of S13 $\mathrm{Hae}_{\mathrm{III}} 3$ with endonuclease Hind (Fig. 4b, Table 5) gave eight products: $\mathrm{HH} 70, \mathrm{HH} 100,2 \times H$ ind 5 and Hind 8 which were all present in a total Hind $+H_{a e_{\text {III }}}$ digest of S13 RF I DNA and three partial products, $\delta 750, \delta 950$, and 6420. By examination of the size of all eight products one arrangement only is possible. $\delta 750$ is a combination of Hind $5 \mathrm{a}$ + Hind $5 \mathrm{~b}+H$ ind $8+\mathrm{HH} 100 ; \delta 450$ is a combination of Hind $8+H$ ind $5 \mathrm{~b}+$ $\mathrm{HH} 100$; and $\delta 420$ is a combination of $\mathrm{HH} 70$ $+H$ ind $5 \mathrm{a}+$ Hind 8 . The arrangement of the fragments in $\mathrm{S} 13 \mathrm{Hae}_{\mathrm{III}}$ is:

$$
\begin{aligned}
& \text { HH70 - } \\
& 8750 \\
& 6420 \\
& \delta 450
\end{aligned}
$$

The products obtained by complete cross-digestion of $H$ ind fragments with

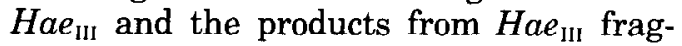
ments digested to completion with Hind were compared with the products of a complete Hind + Hae ${ }_{\text {III }}$ digest of S13 RF I DNA to determine which products were in common with each other. This gave the necessary overlap information. For example, $H$ ind 3 gave a product $\mathrm{HH} 510$ and Hind $4 \mathrm{c}$, a product $\mathrm{HH} 110$ (Table 4) and identical size products occur with $H$ ind digestion of $H_{a e} 1$ II (see above). Thus, Hind 3 and Hind $4 \mathrm{c}$ overlaps with $H_{a e_{\text {III }}} 1$ can be ordered as follows:

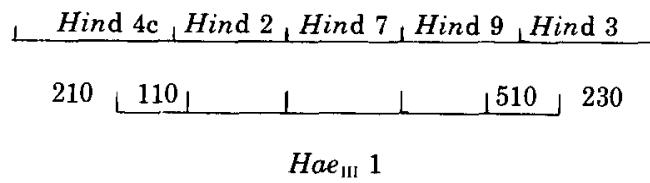




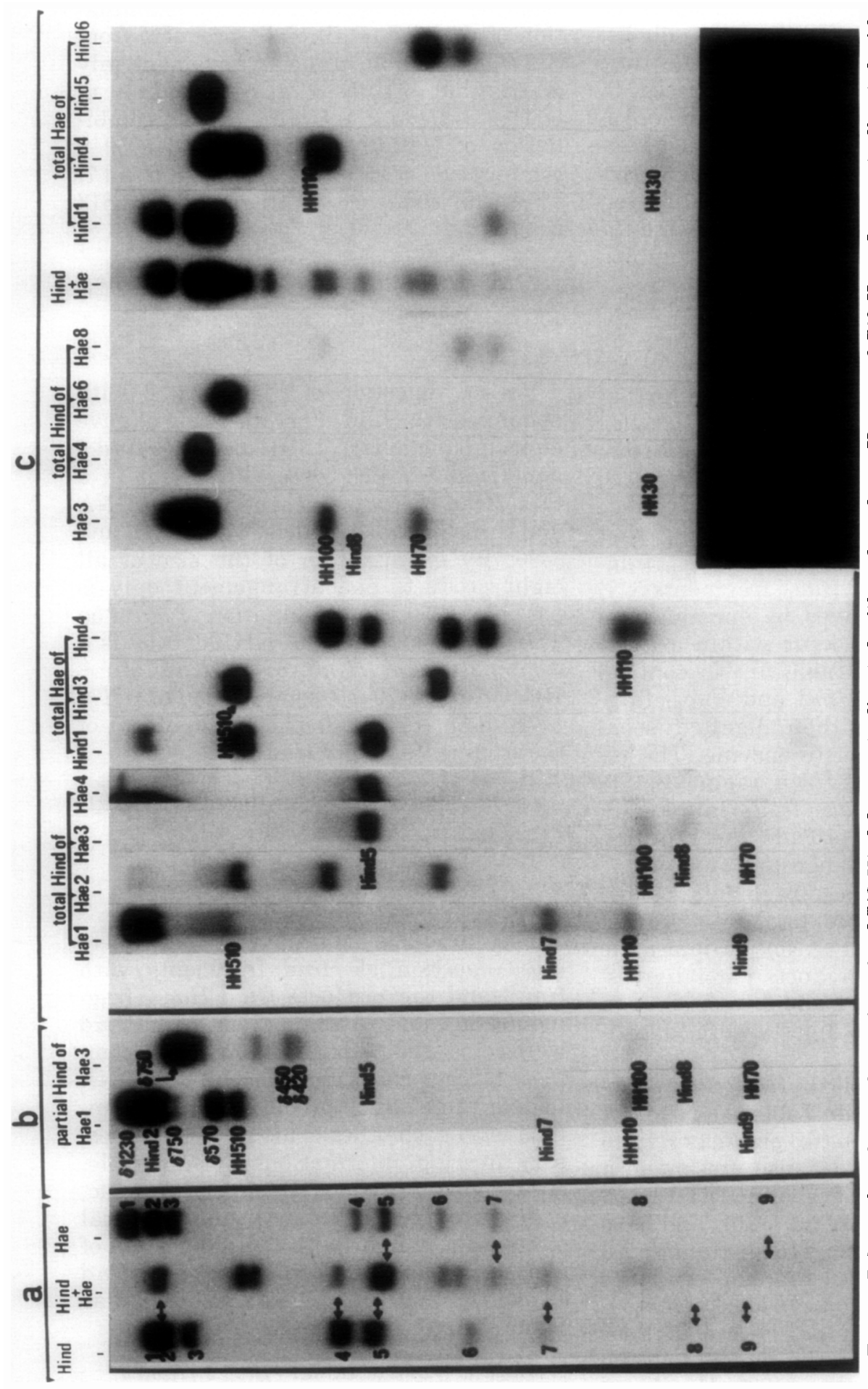

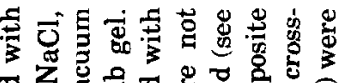

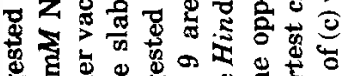

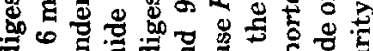
\%

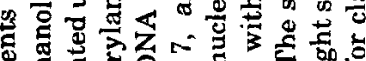
क्ष

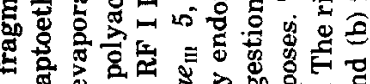
三 进

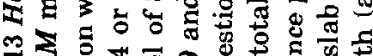

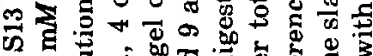
च

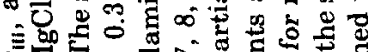

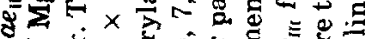

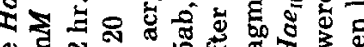
尊

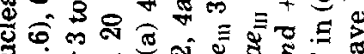
药

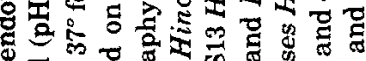

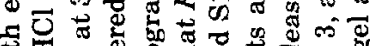
政

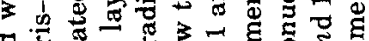
论

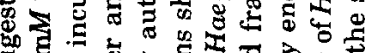
क है

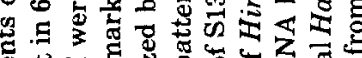

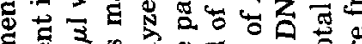

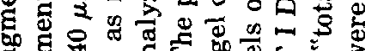

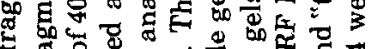

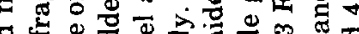

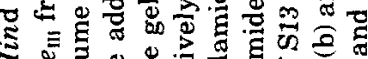
응 क

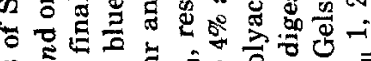

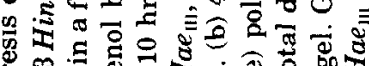

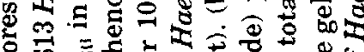
क人 过势

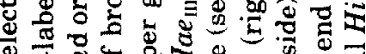

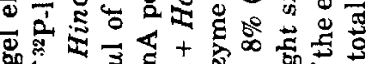

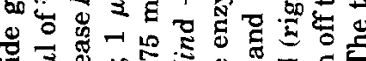

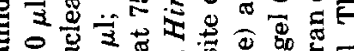
을

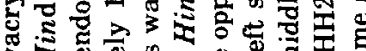

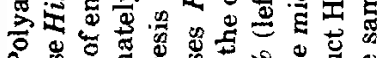

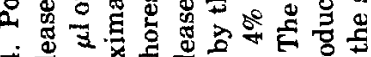
+

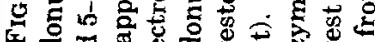

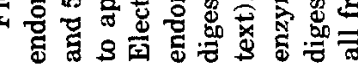


TABLE 4

Redigestion of S13 Hind Fragments bY Hae $e_{11}$

\begin{tabular}{|c|c|c|c|c|}
\hline Fragment & Size & Product with $H a e_{\mathrm{III}}{ }^{b}$ & Product size & Pyrimidine oligonucleotide \\
\hline Hind 1 & 1065 & $\begin{array}{l}\text { HH470 }\left(\text { Hue }_{I I I} 2\right) \\
\text { Hae } \\
\text { HH50 }\left(\text { Hae }_{M 1} 8\right)\end{array}$ & $\begin{array}{r}470 \\
2 \times 270 \\
\quad 50 \\
1060\end{array}$ & $\begin{array}{l}\mathrm{C}_{4} \mathrm{~T}_{3}, \mathrm{C}_{4} \mathrm{~T}_{4}, \mathrm{C}_{4} \mathrm{~T}_{5} \\
\mathrm{C}_{6} \mathrm{~T}, \mathrm{C}_{4} \mathrm{~T}_{3}\end{array}$ \\
\hline Hind 2 & 963 & No hydrolysis & 963 & $\mathrm{C}_{5} \mathrm{~T}, \mathrm{C}_{3} \mathrm{~T}_{5}, \mathrm{C}_{2} \mathrm{~T}_{6}, \mathrm{C}_{4} \mathrm{~T}_{4}, \mathrm{~T}_{7}$ \\
\hline Hind 3 & 721 & $\begin{array}{l}\mathrm{HH} 510\left(H_{a e_{I J}} 1\right) \\
\mathrm{HH} 230\left(H a e_{[I I} 2\right)\end{array}$ & $\begin{array}{l}510 \\
230 \\
740\end{array}$ & $\begin{array}{l}T_{6}, C_{4} T_{2}, C_{3} T_{5} \\
\left(C_{6} T_{3}\right), C_{4} T_{7}\end{array}$ \\
\hline $\begin{array}{c}\text { Hind } 4 \mathrm{a} \\
\mathrm{b}\end{array}$ & 314 & $\begin{array}{l}\text { No hydrolysis } \\
\text { HH210 }\left(\text { Hae }_{\mid \mathrm{III}} 6\right) \\
\text { HH100 }\left(\text { Hae }_{\mathrm{III}} 3\right) \\
\mathrm{Hae}_{\mathrm{III}} 7 \\
\mathrm{HH110}\left(\mathrm{Hae}_{\mathrm{III}} 1\right) \\
\mathrm{HH} 30\left(\text { Hae }_{\mathrm{III}} 4\right)\end{array}$ & $\begin{array}{l}314 \\
210 \\
100 \\
310 \\
170 \\
110 \\
\frac{30}{310}\end{array}$ & $\begin{array}{l}\mathrm{C}_{4} \mathrm{~T}_{4}, \mathrm{C}_{3} \mathrm{~T}_{6} \\
\mathrm{~T}_{6}, \mathrm{CT}_{6 \mathrm{i}}\end{array}$ \\
\hline $\begin{array}{c}\text { Hind } 5 a, b \\
c\end{array}$ & 279 & $\begin{array}{l}\text { No hydrolysis } \\
\text { HH270 }\left(\text { Hae }_{111} 4\right) \\
\text { HH20 }\left(\text { Hae }_{111} 6\right)\end{array}$ & $\begin{array}{r}279 \\
270 \\
20 \\
290\end{array}$ & $\begin{array}{l}\mathrm{C}_{4} \mathrm{~T}_{3}, \mathrm{C}_{2} \mathrm{~T}_{6}, \mathrm{C}_{3} \mathrm{~T}_{8} \\
\mathrm{C}_{4} \mathrm{~T}_{4},\left(\mathrm{C}_{2} \mathrm{~T}_{7}\right) \\
\left(\mathrm{C}_{5} \mathrm{~T}_{4}\right)\end{array}$ \\
\hline Hind 6 & 192 & $\begin{array}{l}\mathrm{Hae}_{\mathrm{III}} 9 \\
\mathrm{HH} 70\left(\mathrm{Hae}_{\mathrm{III}} 3\right) \\
\text { HH57 }\left(\mathrm{Hae}_{\mathrm{III}} 8\right)\end{array}$ & $\begin{array}{r}73 \\
70 \\
57 \\
200\end{array}$ & $\mathrm{C}_{2} \mathrm{~T}_{5}$ \\
\hline Hind 7 & 192 & No hydrolysis & 143 & $\mathrm{C}_{2}{ }^{\prime} \mathrm{T}_{\mathrm{g}}$ \\
\hline Hind 8 & 78 & No hydrolysis & 78 & $\mathrm{C}_{5} \mathrm{~T}_{6}$ \\
\hline Hind 9 & 59 & No hydrolysis & 59 & $\mathrm{C}_{2} \mathrm{~T}_{6}$ \\
\hline
\end{tabular}

"Molecular size in base pairs was estimated from relative mobility in polyacrylamide gels.

'The origin of fragments is denoted by the originating fragment in parentheses. Only HH products of complete digestion are listed.

- Pyrimidine oligonucleotides in parentheses are preliminary assignments.

The final order of all S13 Hind and S13 $\mathrm{Hae}_{\text {III }}$ fragments is given in Fig. 5. To confirm the order all S13 Hind and S13 Hae fragments were subjected to pyrimidine cluster analysis using ionophoresis homochromatography. Since most of the pyrimidine oligonucleotides of S13 which are longer than six nucleotides occur only once or twice per DNA molecule (Cerny et al., 1969), an S13 Hind and S13 Hae ${ }_{H 1}$ fragment containing the same long unique pyrimidine oligonucleotides should be in the same area of the physical map. The results of the analysis of each fragment are given in Tables 4 and 5 and confirm the map shown in Fig. 5.

Relationship of the Hind + Hae ${ }_{n}$ fragment maps of $S 13$ and $\phi X 174$ DNAs. Bacteriophages $\mathrm{S} 13$ and $\phi \mathrm{X} 174$ have identical gene orders in their genetic maps (Jeng et $a l ., 1970$ ). To correlate the restriction enzyme fragment map of S13 DNA with the genetic map, data from $\phi X 174$ DNA restriction enzyme fragment and genetic 
TABLE 5

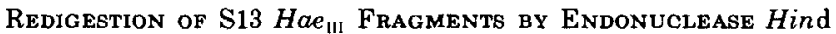

\begin{tabular}{|c|c|c|c|c|}
\hline Fragment & Size $^{a}$ & Product with Hind" & Product size & Pyrimidine Oligonucleotides' \\
\hline$H a e_{111} 1$ & 1690 & $\begin{array}{l}\text { Hind } 2 \\
\text { HH510 (Hind } 3) \\
\text { Hind } 7 \\
\text { HH110 (IIind 4c) } \\
\text { Hind } 9\end{array}$ & $\begin{array}{r}963 \\
510 \\
143 \\
110 \\
59 \\
1785\end{array}$ & $\begin{array}{l}\mathrm{C}_{5} \mathrm{~T}, \mathrm{C}_{3} \mathrm{~T}_{5}, \mathrm{C}_{2} \mathrm{~T}_{6}, \mathrm{C}_{5} \mathrm{~T}_{4}, \mathrm{~T}_{7} \\
\mathrm{~T}_{6}, \mathrm{C}_{5} \mathrm{~T}_{2}, \mathrm{C}_{3} \mathrm{~T}_{5} \\
\mathrm{C}_{2} \mathrm{~T}_{6} \\
\mathrm{C}_{6} \mathrm{~T}_{4} \\
\mathrm{C}_{2} \mathrm{~T}_{6}\end{array}$ \\
\hline$H a e_{\mathrm{HI}} 2$ & 1025 & $\begin{array}{l}\text { HH } 470(\text { Hind } 1) \\
\text { Hind } 4 \\
\text { HH230 (Hind } 3)\end{array}$ & $\begin{array}{r}470 \\
314 \\
230 \\
1014\end{array}$ & $\begin{array}{l}\mathrm{C}_{4} \mathrm{~T}_{3}, \mathrm{C}_{4} \mathrm{~T}_{4}, \mathrm{C}_{4} \mathrm{~T}_{5} \\
\mathrm{C}_{4} \mathrm{~T}_{4}, \mathrm{C}_{3} \mathrm{~T}_{6} \\
\mathrm{C}_{4} \mathrm{~T}_{7},\left(\mathrm{C}_{6} \mathrm{~T}_{3}\right)\end{array}$ \\
\hline$H a e_{\mathrm{III}} 3$ & 863 & $\begin{array}{l}2 \times \text { Hind } 5 \\
\text { HH100 (Hind } 4 \mathrm{~b}) \\
\text { Hind } 8 \\
\text { HH70 }(\text { Hind } 6)\end{array}$ & $\begin{array}{r}2 \times 279 \\
100 \\
78 \\
70 \\
806\end{array}$ & $\begin{array}{l}\mathrm{C}_{4} \mathrm{~T}_{3}, \mathrm{C}_{2} \mathrm{~T}_{6}, \mathrm{C}_{3} \mathrm{~T}_{8} \\
\mathrm{~T}_{6}, \mathrm{CT}_{6} \\
\mathrm{C}_{5} \mathrm{~T}_{6}\end{array}$ \\
\hline$H a e_{m 1} 4$ & 298 & $\begin{array}{l}\mathrm{HH} 270 \text { (Hind } 5 \mathrm{c}) \\
\mathrm{HH} 30(\text { Hind } 4 \mathrm{c})\end{array}$ & $\begin{array}{r}270 \\
\frac{30}{300}\end{array}$ & $\begin{array}{l}\mathrm{C}_{4} \mathrm{~T}_{4},\left(\mathrm{C}_{2} \mathrm{~T}_{7}\right) \\
\mathrm{C}_{5} \mathrm{~T}\end{array}$ \\
\hline$H a e_{111} 5 \mathrm{a}, \mathrm{b}$ & 270 & No hydrolysis & 270 & $\mathrm{C}_{6} \mathrm{~T}, \mathrm{C}_{4} \mathrm{~T}_{3}, \mathrm{C}_{5} \mathrm{~T}_{3}$ \\
\hline$H a e_{111} 6$ & 218 & $\begin{array}{l}\mathrm{HH} 210(\text { Hind } 4 \mathrm{~b}) \\
\mathrm{HH} 20(\text { Hind } 5 \mathrm{c})\end{array}$ & $\begin{array}{r}210 \\
\frac{20}{230}\end{array}$ & $\left(\mathrm{C}_{4} \mathrm{~T}_{4}\right)$ \\
\hline $\mathrm{Hae}_{\mathrm{III}} 7$ & 170 & No hydrolysis & 170 & $\mathrm{C}_{5} \mathrm{~T}_{3}$ \\
\hline$H a e_{\mathrm{III}} 8$ & 107 & $\begin{array}{l}\text { HH57 (Hind 6) } \\
\text { HH50 (Hind 7) }\end{array}$ & $\begin{array}{r}57 \\
50 \\
107\end{array}$ & $\left(\mathrm{C}_{4} \mathrm{~T}_{5}\right)$ \\
\hline$H a e_{111} 9$ & 73 & No hydrolysis & 73 & $\mathrm{C}_{2} \mathrm{~T}_{5}$ \\
\hline
\end{tabular}

"For explanation see footnotes to Table 4.

maps were used. It was necessary to determine first the extent of the differences between the two DNAs. A mixture of ${ }^{32} \mathrm{P}$. labeled S13 RF I DNA and ${ }^{3} \mathrm{H}$-labeled $\phi X 174$ RF I DNA (a gift of Drs. K. Bartok and D. T. Denhardt) was hydrolyzed separately with endonucleases $\mathrm{Hind}$ and $\mathrm{Hae}_{\mathrm{III}}$ and each hydrolysate was separated on polyacrylamide gels. The individual electrophoretic patterns obtained are shown in Figs. $6 a$ and $b$. The peak numbers refer to $\phi \times 174$ Hind and $\phi \times 174 \mathrm{Hae}_{\mathrm{II}}$ fragments as reported by Edgell et al. (1972), and Middleton et al. (1972). The S13 RF I DNA Hind hydrolysate contained a fragment larger than any observed in the $\phi \times 174 \mathrm{RF}$ I DNA hydrolysate (S13 Hind 1, Fig. la) and a smaller fragment (see insert Fig. 6a) which had no corresponding fragment in $\phi X 174$ RF I DNA (S13 Hind 8, Fig. 1a). Fragments corresponding to $\phi \times 174$ Hind 3,4 , and 5 were absent in the S13 RF I hydrolysate. S13 Hind 5 comprised three Hind fragments (Fig. 2) whereas the corresponding $\phi \times 174$ Hind 7 contained two Hind fragments (Edgell et al., 1972). The S13 RF I DNA Hae III $_{\text {hydrolysate differed }}$ from the $\phi X 174$ RF I DNA Hae ${ }_{\text {III }}$ hydrolysate by the absence of fragments equivalent to $\phi \mathrm{X} 174 \mathrm{Hae}_{\mathrm{III}} 1$ and $\phi \mathrm{X} 174 \mathrm{Hae}_{\mathrm{III}} 4$ 


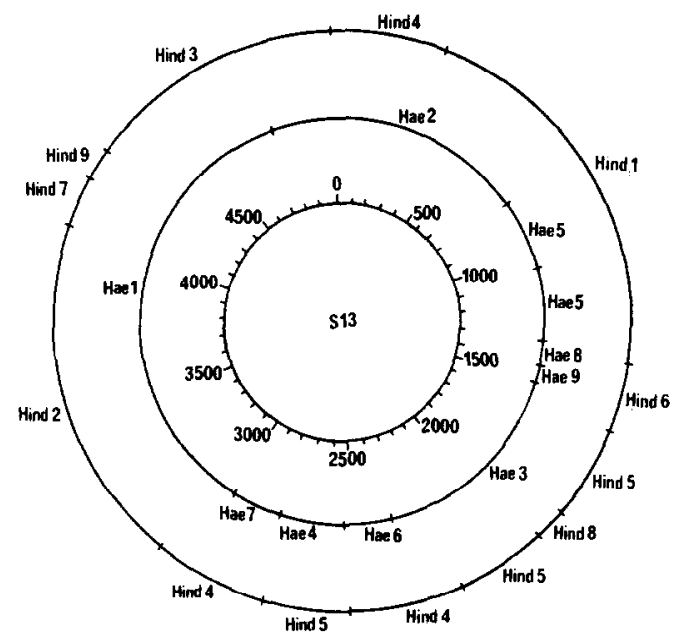

Fig. 5. Physical map of the fragments produced by endonucleases $H$ ind and $\mathrm{Hae}_{\mathrm{III}}$ from S13 RF I DNA. Inner circle is the S13 DNA molecule divided into 5000 base pair units. The middle circle represents the map of the endonuclease $\mathrm{Hae}_{\mathrm{III}}$ fragments, the outer circle the map of the endonuclease Hind fragments.

but a larger band S13 $\mathrm{Hae}_{\mathrm{III}}$ 1, equivalent in size to the sum of $\phi \times 174 \mathrm{Hae}_{\text {III }} 1$ and $\phi \mathrm{X} 174 \mathrm{Hae}_{\mathrm{III}} 4$ was present (Fig. 6b). Correlation of this data with the genetic map is presented in Fig. 7.

\section{DISCUSSION}

Endonucleases $\mathrm{Hind}$ and $\mathrm{Hae}_{\mathrm{III}}$ cleave bacteriophage S13 RF I DNA into 13 and 10 fragments, respectively. The sizes of S13 Hind 1 and 2 determined from electron micrographs and $\mathrm{S} 13 \mathrm{Hind} 7$ and S13 $\mathrm{Hae}_{\mathrm{III}}$ 8 by pyrimidine isostich analysis correlated very well with sizes calculated from integration of the radioactivity of the fragments separated by gel electrophoresis (Fig. 2, Table 3).

Comparison of the endonuclease Hind products of S13 RF I DNA with those from $\phi X 174$ RF I DNA (Fig. 6a) revealed that the same number of fragments are produced from the two DNAs but only S13 $H$ ind 2, 3, 4, 5, 6, 7, and 9 comigrate with $\phi \mathrm{X} 174 \mathrm{Hind} 1,2,6,7,8,9$, and 10 , respectively. Comparison of the endonuclease $H_{a e_{\text {III }}}$ products of S13 RF I DNA with those from $\phi X 174$ RF I DNA (Fig. 6b) revealed that one fragment less is produced from S13 RF I DNA and S13 Hae III $_{2}$, 3, 4, 5, 6, 7,

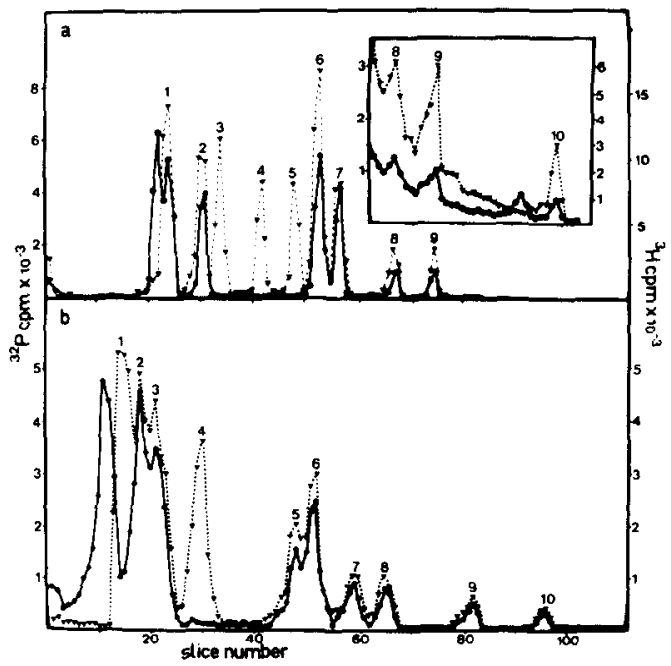

FIG. 6. Polyacrylamide gel electrophoresis of ${ }^{3: 2} \mathrm{P}$. labeled S13 and ${ }^{3} \mathrm{H}$-labeled $\phi \mathrm{X} 174$ RF I DNA fragments produced by (a) endonuclease $H$ ind and (b) endonuclease $\mathrm{Hae}_{\mathrm{III}}$. Twenty micrograms of ${ }^{32} \mathrm{P}$ labeled S13 RF I DNA and $20 \mu \mathrm{g}$ (a) or $50 \mu \mathrm{g}$ (b) of ${ }^{3} \mathrm{H}$-labeled $\phi \mathrm{X} 174 \mathrm{RF}$ I DNA were treated as described in Fig. 1. In Fig. 5a the larger fragments were separated on a $3 \%$ gel the smaller fragments (insert) on a $5 \%$ gel. In Fig. 5b the fragments were separated on a $4 \%$ gel. Slices were $2 \mathrm{~mm}$ thick. Fragment numbers refer to $\phi \mathrm{X} 174$ Hind (a) or $\phi \mathrm{X} 174 \mathrm{Hae}_{11 \mathrm{I}}$ (b), respectively. (-0labeled S13 RF I DNA. (- - - $\left.--_{-}-\nabla_{-}-\right)^{\prime},{ }^{3} \mathrm{H}-$ labeled $\phi$ X174 RF I DNA.

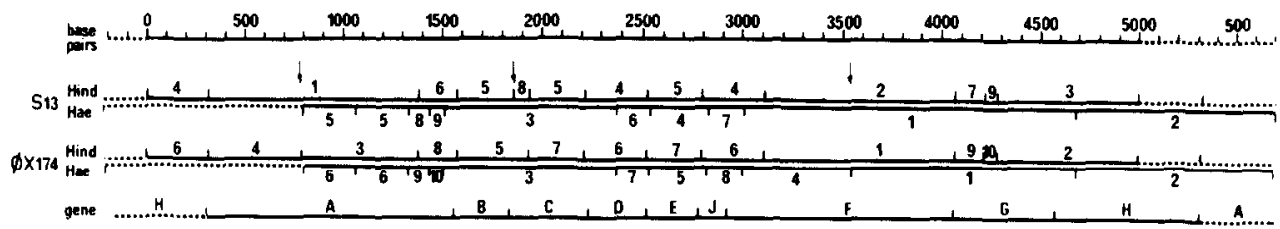

FIG. 7. Comparative map of $\mathrm{S} 13$ and $\phi \times 174 H$ ind and $H a e_{\text {III }}$ fragments and correlation with the genetic map. The genetic map is approximate and referred to by the letters A to $H$ (Jeng et $a l$., 1970). The data on $\phi X 174$ DNA are a composite of studies by Chen et al. (1973), Lee and Sinsheimer (1974) and Johnson and

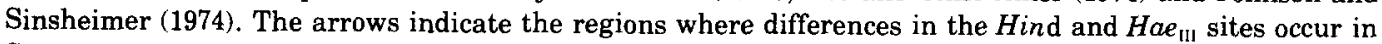
S13 RF I DNA. The dotted lines are representational of the circularity of the maps. 
8, and 9 comigrate with $\phi \mathrm{X} 174 \mathrm{Hae}_{\mathrm{III}} \mathrm{2}, 3$, $5,6,7,8,9$, and 10 , respectively. The other fragments produced by the two enzymes are unique to the two different phages.

Examination of the $\log$ molecular weight versus mobility plot of the S13 Hind and S13 $\mathrm{Hae}_{\mathrm{II}}$ fragments (Fig. 2) indicates that the smaller Hind fragments do not fit a straight line relationship. This has also been observed with $\phi \mathrm{X} 174 \mathrm{Hind} 8$ and 9 in a $5 \%$ gel by Johnson and Sinsheimer (1974), who suggested that this may be due to differences in thymine content in the smaller fragments. However, $\phi \mathrm{X} 174$ Hind 8 and 9 comigrate with S13 Hind 6 and 7 in a $3 \%$ gel (Fig. 6a) and fit the straight line in Fig. 2 as do the similar sized fragments S13 Hae $\mathrm{III} 6$ and 7, whereas $\mathrm{S} 13 \mathrm{Hind} 8$ and 9 fall below the line and $\mathrm{S} 13 \mathrm{Hae}_{\mathrm{III}} 8$ and 9 on the line. The mobility of the smaller fragments is possibly affected by the base composition and nucleotide sequence of the fragments and the gel composition. These data indicate that caution must be exercised in the interpretation of results based on the use of small restriction fragments as size markers in gel electrophoretic separations.

The gene orders of the genetic maps of S13 and $\phi \times 174$ are identical (Jeng et al., $1970)$ and the physical maps of the $\phi \times 174$ Hind and $\phi \mathrm{X} 174 \mathrm{Hae}_{\mathrm{III}}$ fragments have been correlated with the genetic map (Chen et al., 1973; Lee and Sinsheimer, 1974; Johnson and Sinsheimer, 1974). Assuming that the comigrating $\mathrm{S} 13$ and $\phi X 174$ restriction endonuclease fragments correspond to the same parts of the respective DNA molecules, the Hind-Hae ${ }_{\text {III }}$ fragment map of S13 DNA (Fig. 7), deduced from cross-digests and pyrimidine cluster analyses is identical to the $\mathrm{Hind}-\mathrm{Hae}_{\mathrm{III}}$ fragment map of $\phi X 174$ DNA with three exceptions: In the gene $A$ and gene $F$ region one $H$ ind and one $H_{a e}$ III restriction endonuclease site in $\phi \times 174$ DNA have no corresponding site in S13 DNA, while in the gene $\mathrm{B}$ region one Hind site in $\mathrm{S} 13$ DNA has no corresponding site in $\phi \mathrm{X} 174$ DNA (Fig. 7).

The Hind endonuclease recognizes a sequence of six base pairs (Kelly and Smith, 1970) and $H a e_{I I I}$ endonuclease a sequence of four base pairs (Middleton et al., 1972) and the combined Hind, Hae ${ }_{\text {III }}$ enzymes from this study recognize 118 base pairs in S13 DNA. Thus, the data show that from 3 to 16 base pairs may be different in $\mathrm{S} 13$ DNA compared to $\phi \mathrm{X} 174$ DNA and 102115 base pairs are identical in the two phage DNAs. Data from our laboratory (Harbers et al., 1976) indicate that the differences in some other sequences of $\phi X 174$ and S13 are very slight. Recently, Hayashi and Hayashi (1974) have compared the fragments released by the $\mathrm{Hin} \mathrm{H}$ and $\mathrm{Hap}$ restriction nucleases from $\phi \times 174$ and $\mathrm{S} 13$ RF I DNAs and have shown more extensive differences than the ones described here with the Hind and $\mathrm{Hae}_{\text {III }}$ endonucleases. With the Hap endonuclease minimally two out of seven sites are different in S13 DNA compared to $\phi X 174$ DNA and with $\mathrm{Hin} \mathrm{H}$ endonuclease five out of seven sites are changed. The size of the sequence recognition site of $\mathrm{Hap}$ is four base pairs which means that from two to eight out of 28 base pairs are changed in S13 DNA compared to $\phi \mathrm{X} 174 \mathrm{DNA}$. The size of the recognition site of $\operatorname{Hin} \mathrm{H}$ is unknown.

A comparative study of S13 and $\phi \mathrm{X} 174$ DNAs by heteroduplex mapping (Godson, 1973) showed that differences occur in many places in the two phage DNAs with an average 36 out of 100 base pairs mismatched. Only one area of each genome was highly complementary to the other. The distribution of restriction endonuclease sites and long pyrimidine oligonucleotides described in this paper and the $\mathrm{Hin}$ H-Hap physical map described by Hayashi and Hayashi (1974) present defined sequences around the S13 and $\phi \times 174$ genomes with at least one defined sequence per cistron. Also the distribution of the long pyrimidine oligonucleotides indicates that there are no regions in which pyrimidines are clustered. Comparison of the restriction endonuclease defined sequences shows only two differences in the gene A$B$ region and several changes in the gene $\mathrm{F}-\mathrm{H}$ regions of the genetic map of $\mathrm{S} 13$ compared to that of $\phi \times 174$. The total number of base pair changes revealed by the Hind-Hae ${ }_{\text {III }}$ restriction sites taken together with the previous study of pyrimi- 
dine oligonucleotide sequences (Harbers $e t$ al., 1976) of the two DNAs indicate less than a $36 \%$ base mismatch between the two genomes. Comparison of longer sequences from the two DNAs is necessary for definitive conclusions on base sequence similarity between the DNAs, since the sequences reported here may be highly conserved. On the other hand, heteroduplex mapping studies allow only a gross comparison between DNA sequences because nonhydrogen-bonded stretches may contain some relatively short homologous base sequences and hydrogen-bonded stretches some mispaired bases.

Note added in proof. S13 RF I DNA is not cleaved by Hind $\mathrm{d}_{111}$ (Goodchild and Spencer, unpublished results), thus the Hind digests described in this paper are all by $H$ ind $\mathrm{d}_{\mathrm{il}}$.

\section{ACKNOWLEDGMENTS}

The first author is the holder of a Medical Research Council of Canada Studentship. This work was supported by Grant MT 1457 from the Medical Research Council of Canada.

\section{REFERENCES}

Berkowitz, S. A., and DAY, L. A. (1974). Molecular weight of single stranded fd bacteriophage DNA. High speed equilibrium sedimentation and light scattering measurement. Biochemistry 13, 48254831.

Brownlee, G. G., and Sanger, F. (1969). Chromatography of ${ }^{32} \mathrm{P}-$ labeled oligonucleotides on thin layers of DEAE cellulose. Eur. J. Biochem. 11, 395-399.

Burton. K. (1967). Preparation of apurinic acid and of oligodeoxyribonucleotides with formic acid and diphenylamine. In "Methods in Enzymology," Vol. 12A, pp. 222-224. Academic Press, New York.

Cerny, R., Cerna, E., and Spencer, J. H. (1969). Nucleotide clusters in deoxyribonucleic acids. IV. Pyrimidine oligonucleotides of bacteriophage S13suN15 DNA and replicative form DNA. J. Mol. Biol. 46, 145-156.

Chen, C.-Y., Hutchison, C. A. III, and EdGell, M. H. (1973). Isolation and genetic localization of three $\phi X 174$ promotor regions. Nature New Biol. 243, 233-236.

Delaney, A. D., and Spencer, J. H. (1973). Sequence determination of oligonucleotides from S13suN15 DNA. Fed. Proc. 32, 664.

DeLanEy, A. D. (1974). Studies towards the primary structure of S13 DNA. Ph.D. Thesis, McGill University, Montreal, Canada.

Edgell, M. H., Hutchison, C. A., and Sclair, M.
(1972). Specific endonuclease $\mathbf{R}$ fragments of bacteriophage $\phi \mathrm{X} 174$ deoxyribonucleic acid. J. Virol. 9, 574-582.

Godson, G. N. (1973). DNA heteroduplex analysis of the relationship between bacteriophages $\phi \times 174$ and S13. J. Mol. Biol. 77, 467-477.

Harbers, B., Delaney, A. D., Harbers, K., and SPENCER, J. H. (1976). Nucleotide clusters in deoxyribonucleic acids. XI. Comparison of the sequences of the large pyrimidine oligonucleotides of bacteriophages $\mathrm{S} 13$ and $\phi \mathrm{X} 174$. Biochemistry $15,407-414$.

HAYASHI, M. N., and HaYASHI, M. (1974). Fragment maps of $\phi \times 174$ replicative DNA produced by restriction enzymes from Hemophilus aphirophilus and Hemophilus influenzae H1. J.Virol. 14, 1142-1151.

Jeng, Y., Gelfand, D., Hayashi, M., Schleger, R., and Tessman, E. S. (1970). The eight genes of bacteriophages $\phi X 174$ and $S 13$ and comparison of the phage specified proteins. J. Mol. Biol. 49, 521526.

Johnson, P. H., and Sinsheimer, R. L. (1974). Structure of an intermediate in the replication of bacteriophage $\phi \mathrm{X} 174$ deoxyribonucleic acid: the initiation site for DNA replication. J. Mol. Biol. 83, 47-61.

KelLY, T. J., and Smith, H. O. (1970). A restriction enzyme from Hemophilus influenzae. II. Base sequence of the recognition site. J. Mol. Biol. 51, 393-409.

KLEINSChmidt, A. K., and ZAHN, R. K. (1959). Uber Desoxyribonucleinsaüre-Molekuln in ProteinMischfilmen. Z. Naturforsch. 14B, 770-779.

LeE, A. S., and Singheimer, R. L. (1974). A cleavage map of bacteriophage $\phi \mathrm{X} 174$ genome. Proc. Nat. Acad. Sci. USA 71, 2882-2996.

LiNG, V. (1972). Fractionation and sequences of the large pyrimidine oligonucleotides from bacteriophage fd DNA. J. Mol. Biol. 64, 87-102.

LiNG, V. (1972). Pyrimidine sequences from the DNA of bacteriophages $\mathrm{fl}$, fd and $\phi \times 174$. Proc. Nat. Acad. Sci. USA 69, 742-746.

Mrddueton, J. H., EdGell, M. H., and Hutchison, C. A. III (1972). Specific fragmentation of $\phi X 174$ deoxyribonucleic acid produced by a restriction enzyme from Hemophilus aegyptius, endonuclease Z. J. Virol. 10, 42-50.

Schekman, R. W., Iwaya, M., Bromstrup, K., and Denhardt, D. T. (1971). The mechanism of replication of $\phi \mathrm{X} 174$ single-stranded DNA. III. An enzymatic study of the structure of the replicative form II DNA. J. Mol. Biol. 57, 177-199.

Shleger, R., Ishiwa, H., Mannes, B., and Tegsman, E. S. (1968). Early replicative form DNA of bacteriophage S13. I. Sucrose gradient analysis of replicative form made by gene IV mutants. J. Mol. Biol. 34, 121-129. 
Sebring, E. D., Kelly, Jr., T. J., Thoren, M. M., and Salzman, N. P. (1971). Structure of replicating Simian virus 40 deoxyribonucleic acid molecules. J. Virol. 8, 478-490.

Sinshermer, R. L. (1968). Bacteriophage $\phi X 174$ and related viruses. In "Progress in Nucleic Acid Research and Molecular Biology," Vol. 8, pp. 115119. Academic Press, New York.

Smith, H. O, and Wilcox, V. W. (1970). A restriction enzyme from Hemophilus influenzae. I. Puri- fication and general properties. J. Mol. Biol. 51, 379-391.

Smith, H. O., and Nathans, D. (1973). A suggested nomenclature for bacterial host modification and restriction systems and their enzymes. $J$. Mol. Biol. 81, 419-423.

Spencer, J. H., Cerny, R., Cerna, E., and DelaNEY, A. D. (1972). Characterization of bacteriophage S13suN15 single strand and replicative form deoxyribonucleic acid. $J$. Virol. 10, 134-141. 